Members. Algeria, Bahrain, Egypt, Iraq, Kuwait, Libya, Qatar, Saudi Arabia, Syria, Tunisia ${ }^{\star}$, United Arab Emirates. ${ }^{\star}$ Tunisia’s membership was made inactive in 1986.

Headquarters: PO Box 20501, Safat 13066, Kuwait.

Website: http://www.oapecorg.org

Secretary-General: Abdulaziz A. Al-Turki.

Publications. Secretary General's Annual Report (Arabic and English editions); Oil and Arab Co-operation (quarterly; Arabic with English abstracts and bibliography); OAPEC Monthly Bulletin (Arabic and English editions); Energy Resources Monitor (Arabic); OAPEC Annual Statistical Report (Arabic/English).

\section{Organization of the Petroleum Exporting Countries (OPEC)}

Origin and Aims. Founded in Baghdad in 1960 by Iran, Iraq, Kuwait, Saudi Arabia and Venezuela. The principal aims are: to unify the petroleum policies of member countries and determine the best means for safeguarding their interests, individually and collectively; to devise ways and means of ensuring the stabilization of prices in international oil markets with a view to eliminating harmful and unnecessary fluctuations; and to secure a steady income for the producing countries, an efficient, economic and regular supply of petroleum to consuming nations, and a fair return on their capital to those investing in the petroleum industry. It is estimated that OPEC members possess $75 \%$ of the world's known reserves of crude petroleum, of which about two-thirds are in the Middle East. OPEC countries account for about $40 \%$ of world oil production.

Members. (2007) Algeria, Angola, Indonesia, Iran, Iraq, Kuwait, Libya, Nigeria, Qatar, Saudi Arabia, United Arab Emirates and Venezuela. Membership applications may be made by any other country having substantial net exports of crude petroleum, which has fundamentally similar interests to those of member countries. Gabon became an associated member in 1973 and a full member in 1975, but in 1996 withdrew owing to difficulty in meeting its percentage contribution. Ecuador joined the Organization in 1973 but left in 1992. Angola became OPEC's 12th member on 1 Jan. 2007.

Organization. The main organs are the Conference, the Board of Governors and the Secretariat. The Conference, which is the supreme authority meeting at least twice a year, consists of delegations from each member country, normally headed by the respective minister of oil, mines or energy. All decisions, other than those concerning procedural matters, must be adopted unanimously.

Headquarters: Obere Donaustrasse 93, A-1020 Vienna,

Austria.

Website: http://www.opec.org

e-mail: prid@opec.org

Secretary-General: Abdullah Salem al-Badri (Libya).

Publications. Annual Statistical Bulletin; Annual Report; OPEC Bulletin (monthly); OPEC Review (quarterly); OPEC General Information; Monthly Oil Market Report; OPEC Statute.

\section{Further Reading}

Al-Chalabi, F., OPEC at the Crossroads. Oxford, 1989

Skeet, I., OPEC: 25 Years of Prices and Policies. CUP, 1988

\section{OPEC Fund For International Development}

The OPEC Fund for International Development was established in 1976 to provide financial aid on advantageous terms to developing countries (other than OPEC members) and international development agencies whose beneficiaries are developing countries. In 1980 the Fund was transformed into a permanent autonomous international agency and renamed the OPEC Fund for International Development. It is administered by a Ministerial Council and a Governing Board. Each member country is represented on the Council by its finance minister.

The initial endowment of the fund amounted to US\$800m. At the start of 2004 pledged contributions totalled US $\$ 3,435 \mathrm{~m}$., and the Fund had extended 1,024 loans totalling US $\$ 5,845 \cdot 7 \mathrm{~m}$. including US $\$ 4,582.6 \mathrm{~m}$. for project financing, US $\$ 724.2 \mathrm{~m}$. for balance-of-payments support, US $\$ 314.8 \mathrm{~m}$. for programme funding and US $\$ 174.0 \mathrm{~m}$. for debt relief within the context of the Highly Indebted Poor Countries Initiative. In addition, and through its private sector window, the Fund had approved financing worth a total of US\$335.4m. in 67 operations in support of private sector entities in Africa, Asia, Latin America, the Caribbean and Europe. Through its grant programme the Fund had also committed a total of US $\$ 321.7 \mathrm{~m}$. in support of a wide range of initiatives, ranging from technical assistance, research and emergency aid to dedicated operations to combat HIV/AIDS and relief hardship in Palestine.

Headquarters: POB 995, A-1011 Vienna, Austria.

Website: http://www.opecfund.org

e-mail:info@opecfund.org

Director-General: Suleiman Jasir al-Herbish (Saudi Arabia)

\section{Antarctic Treaty}

Antarctica is an island continent some $15.5 \mathrm{~m}$. sq. $\mathrm{km}$ in area which lies almost entirely within the Antarctic Circle. Its surface is composed of an ice sheet over rock, and it is uninhabited except for research and other workers in the course of duty. It is in general ownerless: for countries with territorial claims, see ARGENTINA; AUSTRALIA: Australian Antarctic Territory; CHILE; FRANCE: Southern and Antarctic Territories; NEW ZEALAND: Ross Dependency; NORWAY: Queen Maud Land; UNITED KINGDOM: British Antarctic Territory.

12 countries which had maintained research stations in Antarctica during International Geophysical Year, 1957-58 (Argentina, Australia, Belgium, Chile, France, Japan, New Zealand, Norway, South Africa, the USSR, the UK and the USA) signed the Antarctic Treaty (Washington Treaty) on 1 Dec. 1959. Austria, Brazil, Bulgaria, Canada, China, Colombia, Cuba, Czech Republic, Denmark, Ecuador, Estonia, Finland, Germany, Greece, Guatemala, Hungary, India, Italy, South Korea, North Korea, the Netherlands, Papua New Guinea, Peru, Poland, Romania, Slovakia, Spain, Sweden, Switzerland, Turkey, Ukraine, Uruguay and Venezuela subsequently acceded to the Treaty. The Treaty reserves the Antarctic area south of $60^{\circ} \mathrm{S}$. lat. for peaceful purposes, provides for international co-operation in scientific investigation and research, and preserves, for the duration of the Treaty, the status quo with regard to territorial sovereignty, rights and claims. The Treaty entered into force on 23 June 1961. The 46 nations party to the Treaty (28 full voting signatories and 18 adherents) meet biennially.

An agreement reached in Madrid in April 1991 and signed by all 39 parties in Oct. imposes a ban on mineral exploitation in Antarctica for 50 years, at the end of which any one of the 28 voting parties may request a review conference. After this the ban may be lifted by agreement of three quarters of the nations then voting, which must include the present 28 . 